\title{
The research of the production function of an industrial enterprise
}

\author{
Alexandr Rezepin ${ }^{1}$, Taya Amirova ${ }^{1}$, and Vera Mishina ${ }^{2, *}$ \\ ${ }^{1}$ South Ural State University (national research university), Department of Economic theory, regional economics, state and municipal \\ management, 454080 Chelyabinsk, Russia
}

\begin{abstract}
The article deals with the use of a production function model for the description of production process and the solution of practical problems, such as choice of technological method of production, rational and effective use of invested funds. Analysis of the production process is carried out by the example of Urals Stampings Plant. The analysis consists of two parts. In the first part with the use of regression analysis the production function is evaluated and the elasticity of revenue is calculated on the cost for main types of resources. In the second part of the analysis with the help of artificial neural networks constructing authors investigate the significance of influence the dynamics in the number of production factors and productivity on the physical volume of the issue. In conclusion, the authors provide recommendations for the implementation to increase the level of productivity of the investment strategy for the Urals Stampings Plant.
\end{abstract}

\section{Introduction}

The development of market relations demands much of business entities. They should be able to make independent and effective decisions based on analysis and evaluation of current and future economic situation, clearly formulate the goal of development and work out a strategy to ensure long-term competitive advantages of the company's development. The problem of choosing the technological mode of production and form of reproduction of the basic production assets is largely a problem of rationalizing the volume of invested funds and providing their effectiveness in the long term. Development of the investment strategy of the enterprise is based on the assessment of the production process and the use of economic resources.

\section{The Theoretical Model of Production}

The development of a theoretical model of the production process is the subject of numerous scientific papers. The central place in the theory of production is taken by the question of using a model that can sufficiently describe the manufacturing process. The basic model is a production function. The production function model can be used as a practical tool for solving a number of planning and analytical tasks, such as planning, forecasting and analysis of the enterprise activity.

Theoretical and methodological basis for the application of production functions in the analysis of the product creation process were laid in the works by: C. Cobb and P. Douglas [1], W. Leontief [2], J. Robinson [3], M. Brown [4], R. Solow [5], F. Fisher [6]. The practical issues of the production functions use for solving the problems of production technology optimization and the improvement of resource efficiency were considered by: G. Williams [7], J. McCombie [8], K. Kim [9], W. Dai [10], M. Machado [11], P. McCarthy [12], Y. Dissou [13], J. Sauer [14]. In the Russian scientific works it has developed a usual practice of Cobb-Douglas multiplicative production function application for the applied problems solving in order to provide sustainable development of the company, effective reproduction of economic resources, optimization of material and financial flows. These studies are presented in the works by: B.V. Revazov [15], Yu.A. Shamara [16], R.M. Nizhegorodtsev [17], S.A. Dobrotin [18 ].

The development of methods for modeling of economic and productive situations and decision-making on their basis for planning and forecasting of business activity is a necessary condition to ensure the effectiveness entrepreneurship.

The production function is an economicmathematical relationship between the manufactured products amount and production factors used in their creation. The multiplicative production function is characterized by a partial substitutability of production factors. In practice the most commonly used production function assumes power dependence of production volume on labor and capital. For the first time the power function was applied by C. Cobb and P. Douglas in their work "A Theory of Production" [1] in 1928. They

\footnotetext{
*Corresponding author: mishinavd@susu.ru
} 
empirically established a connection between the labor input, capital and the amount of US manufacturing industry products in the 1899-1922. The multiplicative production function can be used at different levels of the particular enterprise and the entire industry production and the national economy as a whole. It is defined by:

$$
Q=A K^{\alpha} L^{\beta}
$$

where Q - production volume, A - factor of neutral technical progress, $K$ - the amount of production assets, $L$ - the amount of labor used in the production, $\alpha$ and $\beta-$ coefficients of elasticity for the funds and labor.

\section{The production function estimation of an industrial enterprise}

The development of investment strategy of an industrial enterprise bases on an analysis of the production process, which allows identifying the direction of change in technology giving the best return $[19,20]$. To identify the most effective directions of Urals Stampings Plant (Chebarkul, Chelyabinsk Region, Russian Federation) development authors suggested, first, an assessment of the production function and calculation of the revenue elasticity on the costs of the main types of resources, and secondly, to evaluate the contribution of extensive and intensive factors in the change of shipped products volume.

The multiplicative production function is defined by a time series of issues and resource costs. Since the material and human resources used in the manufacture of Urals Stampings Plant products are varied and differ significantly in their productivity, let's consider a function that assigns the revenue and production costs associated with the use of capital and labor resources: (1) amortization of production assets and (2) the salary fund.

The multiplicative production function in logarithms takes a linear form:

$$
\ln \operatorname{Rev}_{t}=\ln A+b_{1} \ln \operatorname{Dep}_{t}+b_{2} \ln \mathrm{Sal}_{t},
$$

where $\ln R e v_{t}$ - the natural logarithm of the enterprise revenue in the period $t, \ln D e p_{t}$ - the natural logarithm of the fixed capital amortization in the period $t, \ln \mathrm{Sal}_{t}-$ the natural logarithm of the wage fund in the period $t, b_{1}$ and $b_{2}$ - the model parameters.

Parameters of $b_{1}$ and $b_{2}$ functions can be determined by least square method of multiple regression using the statistical package in IBM SPSS Statistics.

The regression model has been constructed on the Urals Stampings Plant quarterly financial statements for the 2009-2016 years. ${ }^{1}$ The analysis results are reported in tables 1, 2 and 3.

Table 1. Model Summary .

\begin{tabular}{|c|c|c|c|c|}
\hline Model & R & R Square & $\begin{array}{c}\text { Adjusted } \\
\text { R Square }\end{array}$ & $\begin{array}{c}\text { Std. Error of } \\
\text { the Estimate }\end{array}$ \\
\hline 1 & $0.930^{\mathrm{a}}$ & 0.864 & 0.855 & 0.10183 \\
\hline
\end{tabular}

a. Predictors: (Constant), $\ln S a l, \ln D e p$

1 The official web-site of Urals Stampings Plant. - URL: http://www.mechel.com/sector/steel/urals_stampings_plant.

\begin{tabular}{|l|c|c|c|c|}
\hline Model & R & R Square & $\begin{array}{c}\text { Adjusted } \\
\text { R Square }\end{array}$ & $\begin{array}{c}\text { Std. Error of } \\
\text { the Estimate }\end{array}$ \\
\hline \multicolumn{3}{|c}{ Dependent Variable: $\ln R e v$} \\
\hline
\end{tabular}

\begin{tabular}{|c|c|c|c|c|c|}
\hline Model & $\begin{array}{c}\text { Sum of } \\
\text { Squares }\end{array}$ & df & $\begin{array}{c}\text { Mean } \\
\text { Square }\end{array}$ & $\mathbf{F}$ & Sig. \\
\hline 1 Regression & 1.849 & 2 & 0.924 & 89.141 & $0.000^{\mathrm{b}}$ \\
\hline Residual & 0.290 & 28 & 0.010 & & \\
\hline Total & 2.139 & 30 & & & \\
\hline
\end{tabular}

Table 2. ANOVA ${ }^{\mathrm{a}}$.

b. Predictors: (Constant). $\ln$ Sal. $\ln$ Dep

\begin{tabular}{|c|c|c|c|c|c|c|}
\hline \multirow{2}{*}{\multicolumn{2}{|c|}{ Model }} & \multicolumn{2}{|c|}{$\begin{array}{c}\text { Unstandardized } \\
\text { Coefficients }\end{array}$} & \multirow{2}{*}{$\begin{array}{c}\text { Standardized } \\
\text { Coefficients } \\
\text { Beta } \\
\end{array}$} & \multirow{2}{*}{$\mathbf{t}$} & \multirow{2}{*}{ Sig. } \\
\hline & & B & $\begin{array}{c}\text { Std. } \\
\text { Error }\end{array}$ & & & \\
\hline \multirow[t]{3}{*}{1} & (Constant) & 8.994 & 0.491 & & 18.322 & 0.000 \\
\hline & LnDep & 0.151 & 0.040 & 0.344 & 3.779 & 0.001 \\
\hline & LnSal & 0.649 & 0.053 & 1.113 & 12.238 & 0.000 \\
\hline
\end{tabular}

Table 3. Coefficients ${ }^{\mathrm{a}}$.

a. Dependent Variable: $\ln R e v$

$\mathrm{R}$ Square equal to 0.864 indicates the significant share of explained variance and high quality of a regression model. Dispersion analysis indicates the significance of the regression equation. The coefficients of the regression equation are significant on the basis of Student's t-test.

According to the analysis of the production function of the company is as follows:

$$
\text { Rev }=0.026 \text { Dep }^{0.151} \mathrm{Sal}^{0.649}
$$

where $R e v$ - company revenues. Dep - amortization of fixed capital. $S a l$ - the salary fund.

The elasticity of revenue on the cost of labor is much higher than the elasticity of revenue for fixed capital costs. The increase of labor productivity and salary costs by $1 \%$ is accompanied by the increase in revenue up to $0.649 \%$. This indicates the high significance of human resources in the formation production cost.

The sum of exponents in powers of resulting model is less than one. In theoretical issues this means that the production is associated with negative economies of scale. but with regard to this model it is connected with taking into account capital assets only.

\section{Analysis of the production factors}

To investigate the importance of the changes in the number of production factors impact and their productivity on the physical volume of Urals Stampings Plant. let's analyze the method of artificial neural networks. This method is realized through the defining as the dependent variable the volume of shipped products (Prod). as independent variables: (1) the amount of fixed assets (Capital). (2) Average number of employees (Labour). (3) labor productivity (LabProd) and (4) return on assets (CapProd). The model is constructed on the quarterly data of Urals Stampings 
Plant financial statements in 2009-2016. Network Diagram is represented in Fig. 1.

The model is characterized by high quality of Relative Error in Training and Testing samples. They are equal to 0.004 and 0.007 respectively. Predicted and observed values generally coincide (Fig. 2).

Table 4. Model Summary ${ }^{\mathrm{a}}$.

\begin{tabular}{|ll|r|}
\hline & Model & \multicolumn{1}{|c|}{ Sum of Squares } \\
\hline Training & Sum of Squares Error & 0.042 \\
& Relative Error & 0.004 \\
& Stopping Rule Used & 1 consecutive step(s) with \\
& no decrease in error \\
& Training Time & $0: 00: 00.00$ \\
\hline
\end{tabular}

\begin{tabular}{|ll|r|}
\hline & Model & \multicolumn{1}{|c|}{ Sum of Squares } \\
\hline Testing & Sum of Squares Error & 0.035 \\
& Relative Error & 0.007 \\
\hline \multicolumn{2}{|c}{${ }^{\text {a. }}$ Dependent Variable: $\ln R e v$} \\
& b. Error computations are based on the testing sample
\end{tabular}

According to the results of the analysis of the independent variables importance it may be noted that changes in the number and productivity of the labor force account for $83.7 \%$ of the dynamics in shipped products volume. But only $16.3 \%$ fell to share fixed assets. The intensity change factors provide $51 \%$ of the production volume. and extensive factors provide $49 \%$ (Fig. 3).

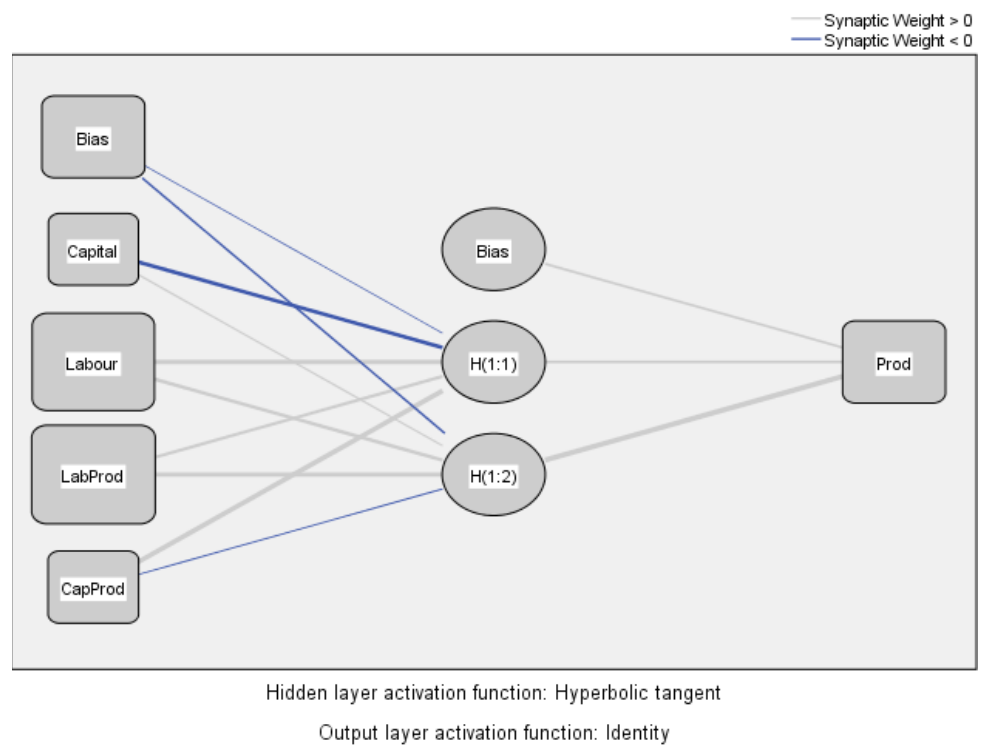

Fig. 1. Network Diagram.

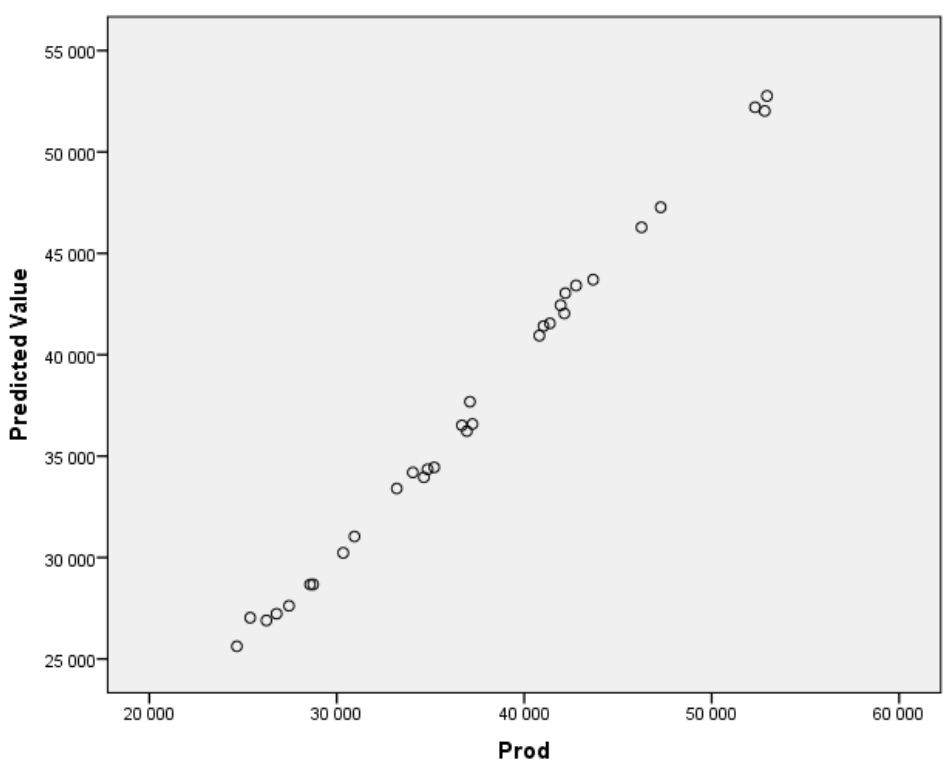

Fig. 2. Predicted by Observed Chart. 


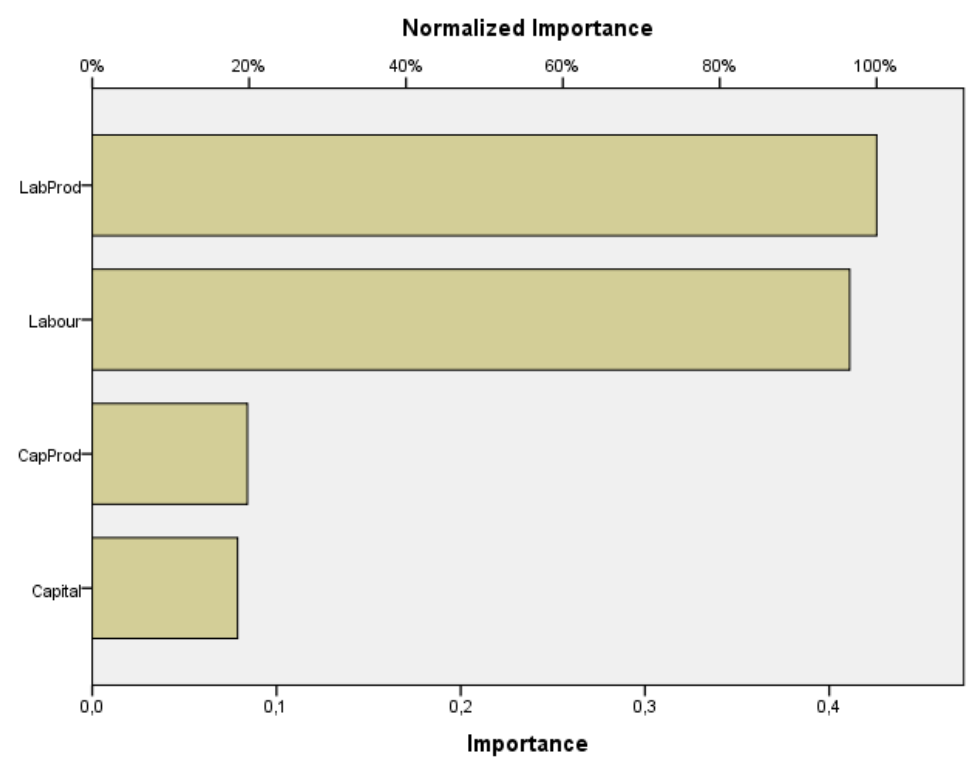

Fig. 3. Independent Variable Importance Chart.

Thus the most significant improvements in physical quantity and value of production can be achieved by changing technologies that promote the productivity of labor in the Urals Stampings Plant. The investment strategy of the enterprise should be changed in accordance with the studied parameters.

According to the result of the research the authors suggest that the point of productivity increase is in the area of human resources. The investment strategy of the enterprise should include the development and use of technologies aimed at the following points.

- Improvement the safety at work. prevention of occupational accidents and diseases.

- Improvement of labor norming system. the implementation of scientifically based set of norms and regulations.

- Establishment of a balanced scorecard of material and moral stimulation and motivation system.

- Provision of training. education and development of human resources within the organization.

The work was supported by Act 211 Government of the Russian Federation. contract № 02.A03.21.0011.

The authors would like to thank the management of Urals Stampings Plant for the full and timely provided information in the field of accounting and management reporting.

\section{References}

1. C.W. Cobb. P.H. Douglas. A Theory of Production. 18. 1.139 (1928)

2. W.W. Leontief. A Note on the Interrelation of Subsets of Independent Variables of a Continuous Function with Continuous First Derivatives. 3. 343 (1947)

3. J. Robinson. The production function and the theory of capital. 21. 81 (1953)
4. M. Brown. W.W. Chang. Capital Aggregation in a General Equilibrium Model of Production. 44. 1179 (1976)

5. F.M. Fisher. R.M. Solow. J.M. Kearl. Aggregate production functions: Some ces experiments. 44. 305 (1977)

6. F.M. Fisher. Aggregate Production Functions Revisited: The Mobility of Capital and the Rigidity of Thought. 49. 615 (1982)

7. G.H. Williams. Use of a production function to estimate the impact of work fragmentation on labor productivity. 11 (2011)

8. J.S.L. McCombie. M.R.M. Spreafico. Cambridge Journal of Economics. 40. 1117 (2016)

9. K.I. Kim. A. Petrin. S. Song. Journal of Econometrics. 190. 267 (2016)

10. Wei Dai. Xiaojun Zhou. International Conference of Information Technology. Computer Engineering and Management Sciences. 4. 53 (2011)

11. M.M. Machado. M.C.S. de Sousa. G. Hewings. Energy Economics. 59. 290 (2016)

12. J. Sauer. C.J. Morrison Paul. Applied Economics. 45. 1461 (2013)

13. Y. Dissou. L. Karnizova. Q. Sun. Atlantic Economic Journal. 43. 107 (2015)

14. P. McCarthy. A. Urmanbetova. Applied Economics. 43. 2883 (2011)

15. B.V. Revazov. Terra economicus. 4. 310 (2007)

16. Yu.A. Shamara. E.B. Smirnov. Bulletin of Civil Engineers. 6. 237 (2013)

17. R.M. Nizhegorodtsev. N.P. Gorid'ko. Journal of Economic Theory. 3. 272 (2013)

18. S.A. Dobrotin. E.A. Suchkov. A.N. Lyabina. Science and world. 3. 8 (2015)

19. B.O. Blashentsev. M.A. Shatalov. Scientific discussions. 8. 51 (2015)

20. G.A. Ryskulova. Bulletin of KRSU. 13. 51 (2013) 